By N. R. KAMPENGA

\title{
Service Area of a Teachers College Library in Cooperation with the War Program
}

Mr. Kampenga is librarian, Central State Teachers College, Stevens Point, Wis. This is the fourth of four papers presented before the Libraries of Teacher-Training Institutions Section of the A.C.R.L., June 24, 1942.

W Hen Miss Floyd asked me to contribute something on the subject, "Service area of a teachers college library in cooperation with the war program," I accepted the invitation without considering too well just why Wisconsin Central State Teachers College experiences would make me qualified to present this subject. Undoubtedly there are other librarians whose libraries are in states blessed with a master regional plan of library influence or whose libraries are part of an area under a library wartime council, such as the Newark Wartime Council in which New Jersey State Teachers College has a place. The experiences of such libraries within a service area that is planned on an organized scale must be particularly full. There are, too, I am sure, librarians of average and small-sized teachers colleges whose experiences in this war effort would be more vivid, whose contributions would be of more value to us. As it is, I figured that since our college at Stevens Point is an average-sized teachers college, with a somewhat better than average library (if statistics mean anything), and situated in an average-sized community of fifteen thousand, our experiences would be typical. Conversation with a few college librarians has convinced me that we are below average in our extramural war services. Wisconsin Central State's service area, although never defined for the library, would extend from north of Madison up the middle of the state to the northern reaches, being predominately rural-trading country, with a few small manufacturing cities and covering some rich farm land, much sandy potato soil, and vast woodlands and pine barrens. For the few requests received from Wisconsin citizens within this area asking for aid in books, in documents, in pamphlets, references or information, it has never occurred to me to look up to see if a particular request came from an alumnus. In every instance we were glad to do whatever we were able. Contemplation of the problem of extending services in actuality, especially as a subsidiary war information center, within this area has led me to accept a challenge and to deal with this problem more forthrightly.

Not much detail of individual college wartime library effort, its progress and results (if measurable), has yet appeared in print.

I doubt if there is a library in the coun- 
try that by now has not declared itself a war information center. The steady campaigns of the U.S. Office of Education, the American Library Association, and others have made all librarians-big and littlewar information conscious. These campaigns themselves grew out of the voluntary efforts of innumerable college and public libraries performing what they considered their place in their community of service. In the beginning it was a display or table or. shelf or list of books, pamphlets, documents, or other materials. As naturally as we change our displays of books to meet current and changing interests, we changed the sign and the materials on that table from "propaganda analysis" (before that probably "world peace") to "fascism, democracy, and communism," to "defense services and selective service information," and finally to "war service opportunities and war information." It was part of the college librarian's contribution to the general education and welfare of the college student. We never would have deprived the public in general of the use of this material. In most cases it was not called to public attention. I think we thought of this service as the proper sphere of the public library and of the state and university extension services. Now it has become "our patriotic duty to exploit to the full our resources in printed materials in the interest of national defense." These are the words of a great librarian, William Warner Bishop.

\section{Not a New Development}

Extending service is not a new development for college libraries, although there may be signs in the development of our war service programs of a wider expansion of service areas for the future. I believe we should seize every opportunity and use every bit of publicity to make available our services, as far as we are able and as long as it does not interfere with our services to students. In general, extension of the services of a teachers college to the surrounding area is handicapped by the lack of funds. During the last three years I recall having attended a panel discussion with teachers college presidents participating and having listened to an address by a teachers college president on the extension of teachers college services. In every instance, the presidents were not unwilling, in fact they were very willing to extend services of every kind, but they had no funds.

\section{New Outlook}

We are not thinking nor talking of funds as much these days as we did during those glory days of the great depression. In these days of crisis our interest is in national morale, in national safety. Doing what appear to be nonessentials worries us. We have given up purchases from our desiderata list; the reference works which we regarded as indispensable are now not so necessary; the gap in the periodical file is not so large; we have forgotten about strengthening that botany collection. Instead, we are purchasing heavily in wartime books (books on war service opportunities, war information in general, and the peace to come after victory). We are purchasing with care, of course, because these perilous times have brought forth an even greater flood of valueless and repetitious books than in the days of security just past. These books and pamphlets-and do not forget the pamphlets nor the government publications nor the clippings-plus the books already on our shelves to meet curriculum 
needs, in nutrition, health, consumer problems, aviation, radio, mathematics, chemistry, even to chemistry of explosives and manufacture of firearms; all these materials make our libraries war information centers. We should, of course, make these available to our areas of service. The citizens within this area, especially those in the rural, village, and small town communities, will have to be told our war information library is open for their use; they will have to be told via the publicity of local, county, and state defense councils, via the newspapers in the region, via radio, via the parent-teacher associations, via the rural school supervisors and commissioners, via the granges and other rural groups, via the trade unions. By then, we shall have done our bit.

War information centers have come into being for the most part through voluntary effort. The U.S. Office of Education has, however, designated 142 (as of May I 5) colleges and universities over the country as key centers of information and training, these activities centering for the most part in administrative officials and in the extension divisions of these institutions. The key centers are strategically located and as such receive special materials and exhibits. Several teachers colleges have been so designated as key centers. These lists have appeared in Education for Victory, a periodical, by the way, which is full of suggestions for the war program.

As early as September I94I the U.S. Office of Education had published a bulletin entitled School and College Civilian Morale Service: How to Participate which outlined a vigorous program of action, the major portion revolving about the maintenance of "a library of information on all phases of the national defense program and the social and economic problems emerging from the crisis."

The joint memorandum of the American Library Association and two other groups on our war participation, appearing in the March 1942 Bulletin of the Association, should be reread as our code of action.

\section{Programs of Services}

As you know, several all-out programs on the services of large college and university libraries have been outlined in recent numbers of the A.L.A. Bulletin by Charles H. Brown, of Iowa State College Library, Charles E. Rush, of the University of North Carolina Library, and by Carl M. White, of the University of Illinois Library. The fact that, for the most part, civilian programs were emphasized over student programs should be noted. The suggestions in each case are applicable on a modified scale to a teachers college library's wartime program in its own community and area of service. The A.L.A. has issued a list of seventy suggestions for library war service, many of which are pertinent to our situations. We should also take advantage of the splendid Guides to Defense Materials prepared by the Library of Congress and issued by the U.S. Information Service. With interlibrary loan at our disposal, with awareness of the existence of these officially designated regional war information centers, the average teachers college library can and should offer services off campus in the same categories outlined for larger colleges and universities.

To local defense councils we should offer our cooperation. As an institution in a small city much of the community and county defense work has centered in the state teachers college at Stevens Point. 
The library was called upon to furnish materials in nutrition and health. Having purchased and collected materials in these fields especially to meet renewed curriculum interests, we were ready and willing to place these materials on special shelves for county and community classes. This was true also in the case of materials of value to defense courses for radio technicians and for aviation groundwork, also for citizen defense corps. These activities are probably typical of what has taken place in teachers colleges all over the country.

\section{A Publicity Agency}

To state and national defense agencies, as well as local, the library will have an opportunity to serve as a publicity agency, if only in matters of displaying materials and in distributing pamphlets.

To radio listeners, where facilities are at the disposal of the college, the library can and should present discussions of books and periodical articles and other materials relating to the war. The director of the Central State Teachers College radio station has asked the library to arrange and present a series of half-hour programs on this theme in this coming school year. I look forward with considerable interest to this experience. With all its limitations, radio can be used as an effective medium for bringing the idea of the college war information center to citizens in the rural communities.

To all citizens who need information obtainable from books and other library materials we should now be prepared to give service. This includes, of course, teachers, clubs, discussion groups, and others.

During the coming year, with the rural communities facing a teacher shortage, we should be prepared and willing to give assistance and furnish teaching aids and curriculum materials to recruit, relief, and refresher teachers who have been away from teaching and now in this emergency return to it.

It is especially important that we give emphasis to this victory's peace, to the world after the peace, and to the preservation of democratic ideals. These causes give our war information service body, dignity, and continuity, hold us bound to a prime function of librarianship-the relationship of the present to the past and to the future. To that cause we are devoted and, although at crises such as Singapore, Java, and the fall of Tobruk, we may feel that this is overemphasized, by all means let us hold fast to and actively encourage direction of thought in the idea of the peace after victory.

\section{Library Is Playing a Part}

There have been developments at Central State Teachers College in this regard in which the library has played an important part. These developments should be of special influence in bringing our war information service to community and area. This last year, in part in order to meet the needs of wartime adjustments in the college curriculum, we made special purchases of books in the fields of international relations, U.S. foreign relations, Latin American relations, with particular emphasis on political and economic history, with special attention to the 1920's and the 1930's, the failure of the Versailles Pact and the League of Nations. If the people of this area would make use of these special collections the library could exert considerable influence as a war service center.

An event in the peace effort of our war 
information center came in an opportunity to propose to a small social science club of the college that it become associated with the International Relations Club. The loan collection of books received through this from the Carnegie Endowment for International Peace was placed in the library. With these books and our own collections in international relations as a foundation, these select and serious students of world peace problems have given panel discussions and debates before local service clubs and before groups in communities near Stevens Point. Next year the club is planning to extend these activities and is contemplating a series of radio talks on war and peace. This is indirect extension service but effective withal and one that needs a librarian's cooperation.

\section{Canby's Statement}

We have been reading in the current issue of the Saturday Review of Literature Henry Seidel Canby's commencement address entitled "Books in Wartime." I would like to quote the concluding paragraph.

The country laughed when Churchill called Mussolini the great miscalculator. But how the French miscalculated after the last war when they thought they could clamp down peace and security on Europe! How we miscalculated when we thought we could keep out of trouble by withdrawing from world settlement while continuing to do business with the world! How the Austrians miscalculated at the beginning of that war when they tried to smother their Serbian difficulties in a European conflict! Was there no wisdom available? Plenty. A historian can supply you with a bibliography of good books published before each event and showing its inevitable failure. But the leaders did not want to use their filing cases because they had immediate purposes of their own, and the people never opened theirs and were easily misled. In the old wars of Greece they used to say to the citizens, come back with your shields or on them. I say to the reader, whatever else you do for your country, don't, when it comes to ideas, be dumb.

This paragraph has particular meaning for librarians. If you care to, you can substitute "librarian" for "historian," and "libraries" for "filing cases."

We cannot tell what social changes will come out of this war. We only know what tremendous changes came out of the major wars of the past. In our small place as teachers college librarians, under the call that "it is our patriotic duty to exploit to the full our resources of printed materials" in this, our cause, we may be moving toward that goal of regional librarianship in which teachers college libraries will undoubtedly take a place. This is true in that we do have responsibilities of community service, if only in the fact that our colleges train teachers to take positions of importance within the region and need the continued assistance of a key library center.

I should like to recommend as our basis of action in developing our centers of information for these times the Educational Policies Commission's remarkable study The Education of Free Men in American Democracy. 